\title{
Policy implementation of local governments in waste management in Dili City, Timor Leste
}

\author{
Leonio Maria Da Silva ${ }^{1 *}$, Nursalam ${ }^{2}$, Hendrik Toda ${ }^{3}$ \\ Universidade Dili, Dili, Timor Leste ${ }^{1 *}$ \\ Nusa Cendana University, Kupang, Indonesia ${ }^{2,3}$ \\ leoniodasilva7@gmail.com
}

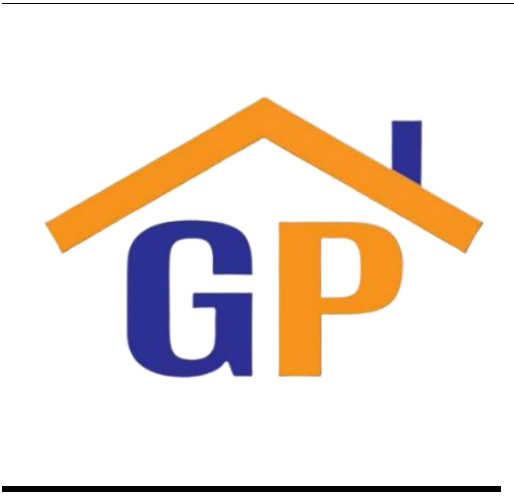

Article History

Received on 16 September 2020

$1^{\text {st }}$ Revision on 24 September 2020

$2^{\text {nd }}$ Revision on 18 December 2020

Accepted on 23 December 2020

\begin{abstract}
Purpose: The purpose of this research is to analyze Policy Implementation of Local Government in Waste Management (Distrito) Dili City, Timor Leste.
\end{abstract}

Research Methodology: The research method used in this research is descriptive research method with a qualitative approach.

Results: The findings in this study are that there are many deficiencies in terms of both content of policy and policy implementation.

Limitations: this research only analyzes the implementation of Local Government In Waste Management (Distrito) Dili City, Timor Leste.

Contribution: This research becomes scientific information for public administration science.

Keywords: Waste management, Content of policy, Policy implementation

How to cite: Da Silva, L. M., Nursalam., Toda, H., \& Ribeiro, A. (2021). Policy implementation of local governments in waste management in Dili City, Timor Leste. Journal of Governance and Accountability Studies, 1(1), 1-13.

\section{Introduction}

All countries in the world have problems in their respective countries. The problems that exist in each country vary, such as economic, demographic, social and cultural problems to the problem of waste. Problems related to waste management do not only occur in developed countries but are also one of the main problems in Dili, Timor Leste. Timor Leste is a small country with an area of 14,609, $38 \mathrm{~km}^{2}$ consisting of thirteen (13) Distrits. Dili District is used as the capital of the State of Timor Leste because it is the smallest area with an area of about $372 \mathrm{~km}^{2}$ (Ministry of Internal Affairs of Timor Leste, 2020).

With the determination of the City (Distrito) of Dili as the capital of Timor Leste, autom1atically all activities of the people of Timor Leste will largely be very centralized and concentrated in the city of Dili. This community activity, which is concentrated in one location, is one of the causes of the increasing volume of waste in Dili. It is known that waste management in Dili City is still not optimal, with the largest volume of waste coming from housing / residential and market waste. The composition of waste from each source is generally different, namely waste from housing consists mostly of organic waste (food scraps, rotting vegetables and fruits), and while waste from shops and markets are inorganic waste such as plastics, cans, bottles and paper. The waste produced by schools and hospitals consists of paper, bottles and plastic and the composition of waste from public places such as terminals is plastic, paper and leftover food. In Distrito Dili Timor Leste, the highest amount of waste generation is found in 4 (four) districts in Distrito Dili Timor Leste, namely Nain Feto, Dorn Alexio and Cristo Rei and Curon Vera Cruz.

Another problem is that the people of Dili City view that tackling the waste problem is the sole responsibility of the government. The community plays a more role only as the party who wants to be 
served because people think that the government already has a policy for city cleanliness on every Friday in Dili, such as a cleanliness program for office environments, beaches, public roads and markets. Whereas currently there is a system that is better and more efficient and considered modern, namely the concept of zero waste, by implementing integrated non-organic waste management, reducing the volume of waste from sources by means of recycling (Alex, 2002: 27).

The disposal of garbage in Dili City is also not balanced with the existing carrying capacity and capacity, so that garbage still piles up on the roadside, in office areas, schools, beaches, and in corners of Dili City. It can be said that the waste management system in Dili-Timor Leste is still classified as using traditional concepts, namely the concept of collect, transport and dispose of. The limited number of means of transporting waste in Dili City is also a problem in waste management efforts. The number of transportation facilities available is only 4 (four) units of trucks and a temporary garbage dump, which is insufficient to accommodate the volume of garbage in Dili City.

In order to solve the various problems related to waste management mentioned above, the Government of the City of Dili is guided by the public policy stated in the Ministry of Home Affairs Regulation Number: 33/2008/08 concerning Guidelines for Waste Management (Republica Democratic de Timor-Leste Decreto Lei Governo 33/2008 Hygiene E Ordem Publicas) which is stated as follows:

1. That in order to create a healthy and clean environment from waste

2. That waste, it is necessary to handle waste in a comprehensive and integrated manner from upstream to downstream.

3. That in the context of handling waste in a comprehensive and integrated manner; it is necessary to involve the participation of the community and the business world proportionally, effectively and efficiently.

Understanding what actually happens after a policy is declared in effect or formulated is the focus of attention to policy implementation, namely events and activities that arise after the implementation of state policy guidelines, covering both efforts to administer it and to cause consequences real impact on society or events. Policy implementation is the actions taken by the government in the form of both programs and decisions about how to achieve the goals or objectives to be achieved which in this case are the recommendations to be achieved from the policy of the Ministry of Home Affairs Regulation Number: 33/2008/08 regarding Guidelines for Waste Management.

With the description previously mentioned, to analyze the success rate of implementing local government policies in waste management in Dili, the author uses the model of policy implementation theory from Merilee S. Grindle (1980: 11) which states that the success of policy implementation is influenced by the content of the policy (content of policy) and the policy environment (content of implementation). The basic idea is that after the policy is transformed, a policy is implemented consisting of content of policy which includes; (a) the interests affected by the policy, (b) the types of benefits generated, (c) the degree of change desired, (d) the position of policy makers, (e) who is implementing the program?, (f) the resources deployed. While the Policy Environment (content of implementation) includes; (a) powers, interests and strategies of the actors involved, (b) characteristics of institutions and authorities, and (c) compliance and responsiveness.

The uniqueness of the Grindle model lies in its comprehensive understanding of the policy context, particularly with regard to implementers, implementation recipients, and the arena of conflict that may occur between implementation actors, as well as the conditions for implementation resources required. Based on the formulation of the background above, the researcher is interested in conducting research with the title "Policy Implementation of Local Governments in Waste Management in Dili City, Timor Leste" 


\section{Literature review}

\subsection{Regional goverment}

Local Government is one of the tools in the governance system. This local government refers to the administrative authority in an area that is smaller than a country where the Indonesian state is a country whose territory is divided into provinces. The provincial area is further divided into regencies and municipalities. Every province, regency, and municipality has a regional government, which is regulated by law. According to The Liang Gie (1994: 44) Regional Government is units of government organizations that are authorized to carry out all local interests from a group that inhabit an area led by the head of the regional government. Regional Government according to W. Riawan (2009: 197) is: "Government in terms of its meaning is the authoritative direction and administration of the affairs of men / women in a nation state, city, etc. In Indonesia as a direction and administration which is authorized for community activities in a country, city and so on. Government can also be interpreted as the governing body of a nation, state, city, etc., namely the institution or agency that administers the government of the State, state, or city and so on. In Timor leste, the central government is the national level government headed by a Prime Minister (PM) and assisted by ministers. Meanwhile, local government is a regional government at the Municipio level headed by an Administrador Municipio (Regent) without going through the provincial level government. Based on Law number 11/2009 concerning the Division of Territorial Administration (Divisão Administrativa do Teritório) of Timor-Leste based on the 12 regions of Muncipio and the Região Administrava Epecial de Oecusse-Ambeno / Special Administrative Region of Oecusse-Ambeno (RAEOA). Região Administrava Epecial de Oecusse-Ambeno is a unitary part of Timor-Leste given the right, obligation and authority to manage its own household through the regional decentralization system.

Then emphasized on Lei No. 11/2009 concerning th-8e division of the Territorial Administration, Article 1 regarding the formation of the Municipio is: $O$ território de Timor-Leste divide-se administrativamente em municípios, sendo que cada um destes compreende uma unidade de poder local, nos thermos da Constituição which can be interpreted as follows: That Timor-Leste is divided administratively into Minucipio regions, each of which consists of local government units under the Constitution and the law. So the Municipio regional government is part of the central government within the jurisdiction of the Republic of Indonesia Democratica de Timor-Leste, and is given the authority to regulate its household, with the central government continuing to strive to complement regional financial resources through general and special allocations to carry out regional government affairs under its authority balancing funds and loans or grants to Municipio local governments.

\subsection{Public policy}

Friedrich 1969 in Agustino (2016: 16) states that policy is a series of actions proposed by a person, group, government or a certain environment by showing the constraints of opportunities for implementing the proposed policy in order to achieve certain goals. Another policy definition put forward by Nugroho (2006: 23) makes a formulation of understanding about public policy. First, public policies are policies made by state administrators or public administrators. So, public policy is everything that the government does and doesn't do. Second. Public policy is a policy that regulates life together or public life, not the life of an individual or individual. Public policy governs everything in the domain of a public administrator institution. Public policy regulates common problems or personal or group problems that have become problems of the entire community in that area. Third, it is said to be a public policy if the benefits obtained by people who are not direct users of the products produced are far greater or greater than the direct users.

The meaning of policy as a series of activities or actions added by Friedrich 1969 in Agustino (2016: 16) defines policy as an action that leads to goals proposed by a person, group or government in a certain environment in connection with certain obstacles while looking for opportunities to achieve goals or realize the desired goals so as to achieve a goal.

Furthermore, Islamy (2004: 33-34) defines state policy as what the government claims to do or not do. The country's policies are the goals or objectives of government programs. According to 
William Dunn (2003: 25) explains that the process of formulating public policy is based on various main stages. The stages in this public policy are described as shown below:

1. Problem Formation

2. Policy Formulation

3. Policy Adaption

4. Policy Implementation

5. Policy Evaluation

From these descriptions it can be seen that public policy is a complex process. However, without reducing the complexity, the authors conclude that public policy is a series of policy processes (decision and action) carried out by the government with the aim of resolving problems that arise in society.

\subsection{Policy implementation}

Implementation with regard to various activities directed at program realization. In this case the administrator arranges the way to organize, interpret and apply the policies that have been selected. Organizing means manage the resources, units and methods for implementing the program. Implementing means using instruments, performing or providing routine services, making payments or in other words implementation is the stage of realizing program objectives. In this case, what needs to be considered is the preparation for implementation, namely thinking and calculating the various possibilities of success and failure including the obstacles or opportunities that exist and the ability of the organization in charge of implementing the Keban program (2014: 76-77). From this explanation, he quoted Nugroho (2006: 158) who stated that policy implementation is a way for a policy to achieve its goals. To implement public policy, there are two choices of steps, namely directly implementing it in the form of programs or through the formulation of derivate policies or derivatives of the public policy. Meanwhile, according to Soenarko (2005: 180) in implementing public policy there are several provisions that must be fulfilled and carried out in order to succeed, these provisions concern the authority of the implementer, the content of the policy, the legitimacy of the people and so on.

A policy will be visible when applied or implemented in the field. Policy implementation is the actions taken by the government in the form of concrete programs and decisions on how to achieve the goals or objectives to be achieved and to overcome the impact of the implementation of the policy and the existence of policy improvements that come from the feedback from the implementation. Implementation in a broad sense, is a legal administration tool where various actors, organizations and technical procedures work together to carry out policies to achieve the impact or goals desired by James P. Lester and Joseph Stewart 2000 in Agustino (2016: 129), while Mazmanian and Sabatier in Agustino (2016: 128) explain that implementation is the implementation of basic policy decisions, usually in the form of laws but can also be in the form of orders or important executive decisions or judicial decisions. In studying policy problems, it means trying to understand what actually happens after a program is executed or formulated, namely events and activities that occur after the process of ratification or legitimacy of public policy, whether it is efforts to administer or efforts to give specific impacts on society or on events.

Understanding good implementation should not only highlight administrative institutions or agencies responsible for a program and its implementation towards target groups, but also need to pay close attention to various networks of political, economic and social forces that directly or indirectly influence behaviors involved in the program that ultimately have an impact on the program (Wahab, 2005: 184-185) while Keban (2014: 76) states that an implementation is related to various activities directed at program realization, in this case the administrator arranges to organize, interpret and apply the policies that have been selected. Interpreting with regard to translating program language or terms into acceptable and feasible plans and instructions, implementing means using instruments, carrying out or providing routine services, making payments, in other words policy implementation is a stage realizing program objectives.

\subsection{Policy implementation model}

According to Merilee S. Grindle (1980: 11), the success of the implementation of local government policies in waste management is influenced by the content of policy, namely the Ministry 
of Home Affairs Regulation Number: 33/2008/08 regarding Guidelines for Waste Management and the environment policy (content of implementation) which in this case is Distrito Dili-Timor Leste.

1. Content of policy includes:

a. The interest that is influenced by the policy in this study is good and correct waste management in the Distrito Dili-Timor Leste.

b. The types of benefits generated in this study are the benefits of good and correct waste management in Distrito Dili-Timor Leste

c. The desired degree of change is the change desired by the Distrito Dili-Timor Leste government regarding the implementation of waste management policies

d. Location of waste management policy decision making in Distrito Dili Timpr Leste

e. Who is the program implementer? The implementation of the waste management policy in Distrito Dili-Timor Leste is left to the Sanitation Office, known as Saniamento

f. Resources devoted to dealing with waste problems in Distrito Dili-Timor Leste

2. While the Policy Environment (content of implementation) includes:

a. Power, interests and strategies of actors involved in implementing waste management policies in Distrito Dili-Timor Leste

b. Characteristics of institutions and authorities in Distrito Dili-Timor Leste

c. Compliance and responsiveness of the community implementing the Distrito Dili-Timor Leste policy.

The advantage of the policy implementation model from Merilee S. Grindle is that it can find out more deeply about the policy implementation activities to be analyzed because this model analyzes the success of a policy implementation through 2 variables, namely the content or content of the policy and the environment or the context of the policy being implemented. It is known whether the implementers of the policy, in this case the Government of the City of Dili, have made a policy in accordance with what is expected, it can also be seen whether a policy in this study is the Ministry of Home Affairs Regulation Number: 33/2008/08 concerning Guidelines for Waste Management influenced by an environment and whether there has been a change as desired.

\subsection{Waste}

Gunawan (2007: 26) states that waste is basically a material that is wasted or disposed of from a source of human activity or natural activity that has no economic value, and can even have a negative economic value because in its handling it is good for disposing or using natural processes. Cleaning it requires a large amount of money. Garbage is a material that has no value or is of no value for ordinary or primary purposes in the manufacture or use of damaged or defective goods in manufacturing or excess or rejected or discarded materials. Furthermore, Hadiwiyoto (1983: 13) defines waste as the remains of materials that have undergone good treatment because the main part has been taken, or because of processing, or because there is no benefit, which from an economic point of view is of no value and in terms of environment can cause pollution or disturbance of sustainability. So it can be said that waste is the remains of material originating from human activities or natural activity that have been discarded because it has no economic value. Mubarak and Chayatin (2009: 275-276) state that waste is divided based on:

1. Based on the origin of the waste:

a. Household waste / domestic waste, namely waste generated from household activities. This category includes waste from dormitories, hospitals, hotels and offices.

b. Industrial waste is waste generated from production activities or industrial waste, both within the scope of industry and small industry or craft industry.

c. Agricultural waste is waste from agricultural waste, including plantations, forestry, livestock and fisheries

d. Trade waste is waste originating from market and shop waste.

e. Waste resulting from construction activities, namely waste originating from scraps or waste from building roads, warehouses or housing, such as rubble, wood, and plastic. 
f. Street sweeping is rubbish from street sweeping which contains various garbage on the road, such as leaves, paper, and plastics. In big cities, it is more numerous and varies in content.

2. Based on the composition

In an activity it is possible to produce the same waste so that the constituent components are the same. For example garbage consisting of paper, pastries, or leaves. Although this waste can be mixed with other materials, some of its components are still composed of similar or uniform components. This kind of waste can be divided into two, namely:

a. Uniform waste, waste that falls into this category usually comes from industries, offices, or photo copy places. It is classified as uniform waste if the waste only consists of paper, plastic or metal

b. Non-uniform waste, for example trash originating from markets, recreation areas, terminals or from other public facilities.

3. Based on the occurrence of the process

a. Natural waste is rubbish that is formed due to natural processes, such as fallen leaves, dead animal waste originating from carcasses such as rats, chickens, and livestock that have become carcasses. The amount is relatively small, but if a natural disaster occurs, a volcano erupts, a long drought kills the surrounding animals, then this garbage becomes a problem.

b. Non-natural waste is waste that is formed and generated due to human activities.

4. Based on the nature

a. Organic waste (garbage) is semi-wet solid waste in the form of organic material which generally comes from the agricultural and food sectors, consisting of leaves, wood, vegetables, food scraps, leftover fruits, animal carcasses and others. This waste contains organic compounds composed of the elements carbon, oxygen and hydrogen, has the characteristics of being broken down by microorganisms and easy to decompose, because it has a relatively short chemical chain.

b. Inorganic waste (rubbish), namely solid waste that is quite dry, is waste that is not composed of organic compounds and is difficult to decompose by microorganisms, making it difficult to rot. This is caused by compounds that have long and complex chemical chains, for example plastics, glass, cans, mica, iron, and other metals.

5. Based on the shape

a. Apart from being solid (solid) and easily visible to the eye, there are also other forms.

b. Ash (ash), which is solid waste in the form of gray, is easily carried away by the wind, because it is light and easy to rot. For example ashes from burning, road dust, ash from construction products.

6. Based on the type

a. Food waste, including animal leftovers.

b. Garden / yard waste.

c. Paper trash.

d. Plastic, rubber, and leather trash.

e. Cloth trash.

f. Wood waste.

g. Metal trash.

h. Glass, glass and metal waste

\subsection{Waste management}

So far, implementing a collection, transport and disposal system has carried out waste management. Waste originating from the community and the area is only collected in one place, then transported and immediately disposed of in a landfill (Zulkifli, 2014: 106). In this process, the sanitary landfill method is used, namely by piling up garbage in the ground known as $4 \mathrm{R}$, which includes:

1. Reduce (reduce): minimize the goods or materials that we use

2. Reuse: choose items that can be reused, avoid using disposable items. 
3. Recycle (recycling): items that are no longer useful can be recycled so that they are useful and have added value. Not all goods can be recycled, but nowadays there are many formal industries and home industries that use waste to become useful and economical goods.

4. Replace (replace): replace items that can only be used once with items that are more durable. In addition, using items that are more environmentally friendly, for example replacing plastic bags with baskets when shopping, and avoiding using Styrofoam because these two materials cannot be degraded naturally.

In the management of household waste and household-like waste, limiting waste piles, recycling of waste, and reusing waste carry out waste reduction. Meanwhile, the handling is carried out by sorting waste, collecting garbage, transporting waste, processing waste, and final processing waste. In the technical implementation of waste management, local governments still need further regulations in dealing with waste problems in their regions. Managing waste from the past can actually be done by the community itself by sorting / separating waste by type. This sorting is for example by dividing whether the waste is dry waste, wet waste, or plastic and bottle waste.

\section{Research methodology}

The research method used in this research is descriptive research method with a qualitative approach. Descriptive method is a method of examining the status of human groups, an object, a condition, a thought or a class of events in the present with the aim of making a systematic, factual and actual description, description or painting of facts, characteristics and the relationship between the phenomena investigated (Nasir, 2005: 54). The purpose of this research is basically to try to find out and analyze the extent of the implementation of policies carried out by the local government in waste management in Distrito Dili-Timor Leste. The source of the ideas in this research comes from empirical sources, observations and also theoretical studies which are currently being discussed by the Distrito Dili-Timor Leste community regarding waste management by the Distrito Dili-Timor Leste government which is still not effective and efficient This research can be used as input for the Distrito Dili-Timor Leste government and the people of Dili City for the further progress of Timor Leste.

\section{Results and discussion}

Grindle (1980: 10) states that in a policy implementation process that is assessed is the design of an action program to influence implementation activities which can later have an impact on the desired community or individual so that from the design and action the program is formulated to be implemented until a goal of a process is achieved the implementation. Referring to the research question, to analyze which waste management policy is implemented in Distrito Dili, Timor Leste, the author uses a policy implementation model from policy implementation from Merilee S. Grindle (1980: 11), which will be discussed further through the discussion below:

\subsection{Content of policy}

4.1.1. Interests affected by policy

The interest that is affected by the policy, in this case is the policy of the Ministry of Home Affairs Regulation Number: 33/2008/08 concerning Guidelines for Waste Management. The interest that this policy wants to influence is the habit of the people of Distrito Dili, Timor Leste, who are not orderly in disposing of garbage. In its implementation, it is known that the highest number of piles of garbage is found in 4 (four) districts in Distrito Dili, Timor Leste, namely Nain Feto, Dorn Alexio and Cristo Rei and Curon Vera Cruz.

The market area is the area with the highest amount of pile of garbage in the four sub-districts in Distiro Dili. If it is related to the interests affected by the policy, it can be said that this has not been effective because in the last 3 years there has been an increase in the amount of waste dumped in Distrito Dili, Timor Leste. This shows that the interests of each individual involved in implementing waste management policies have not been influenced by waste management policies in Distrito Dili, Timor Leste.

The weak influence exerted by this government policy is similar to the findings of Lalitha and Fernando (2019) in their research on Solid waste management of local governments in the Western Province of Sri Lanka: An implementation analysis. They revealed that the waste management 
program is not running efficiently in Sri Lanka due to weak political interference through waste management policies. In addition, Abbas and Wee (2014) in their research entitled The Issues of Policy Implementation on Solid Waste Management in Malaysia stated that waste management policies would not have an effect if they are not effective and there is no commitment from all parties to take them seriously.

\subsubsection{Types of benefits generated}

The Timor Leste government hopes that good waste management will have positive impacts on humans and the environment, such as:

1. Health benefits

2. Environmental benefits

3. Benefits to social conditions

4. Benefits to the economy

Timor-Leste, with a population of only 1.3 million inhabitants, produces around 4.75 million $\mathrm{m}^{3}$ of waste per day while annually it reaches $1,733.75 \mathrm{~m}^{3}$ according to government data. Most of the way it is managed is collected from beaches and urban areas, then only $10 \%$ is burned in the open and most of it is collected in the final disposal site as much as $71 \%$. However, until now, the waste recycling policy is still being implemented at an early stage because it requires large funds and the time for implementation of the policy is at the end of 2020. Lalitha and Fernando (2019) also pointed out the inability to recycle. They said that one of the problems of waste management in Sri Lanka is the government's inability to recycle waste.

\subsubsection{Desired degree of change}

The degree of change desired from the implementation of the Republica Democratic de TimorLeste policy Decreto Lei Governo 33/2008 Hygiene E Ordem Publicas has not been implemented because the behavior pattern of the community has not fully realized the bad effects of the pattern of littering behavior, while not all waste are generated by the Distrito community. Dili Timor Leste can be recycled naturally, such as plastic, metal / metal and glass.

Data obtained from the Saniamento Distrito Dili office found the fact that the average pile or volume of waste per day in Distrito Dili reached $4.75 \mathrm{~m}^{3}$ while annually it reached $1,733.75 \mathrm{~m}^{3}$. These all need special attention because in the collection of waste, the Dili Distrto Government is faced with the problems of facilities and infrastructure such as garbage bins, garbage trucks and wheelbarrows to carry out the transportation at each location of garbage to the landfill. The low awareness of the community in managing waste and the lack of waste disposal and management facilities were also stated by Amir and Anto (2018) in their research entitled A Study policy implementation of waste management in Konawe Regency. They cited the lack of facilities, public awareness and wider community involvement to be some of the factors that prevent waste control from being carried out effectively.

\subsubsection{Decision making}

Making policy decisions in the implementation of local government policies, Distrito Dili Timor Leste based on the Republica Democratic de Timor-Leste policy Cleanliness (Saniamento) in each District in Timor Leste, one of which is Saniamento Distrito Dili. The decision to produce this policy was based on the Bottom-Up decision, where the issues that existed in the people of Timor Leste related to the waste problem were included in the policy agenda. Then the Republica Democratic de Timor-Leste policy was formulated and the Decreto Lei Governo 33/2008 Higiene E policy was born. Ordem Publicas with the hope that in implementing this policy it can change Timor Leste to be cleaner. Bottom-up policy making is the right step in designing a policy, especially a waste management policy. Abbas and Wee (2014) said that policies that are not in accordance with the conditions of a region would not work effectively. This shows that the right policy will have the right impact too.

\subsubsection{Who is the program implementer?}

The central government of Timor Leste is the party that takes the initiative (the initiator) so that the waste management policy becomes a community movement and assigns responsibility to the 
Minister of Environment and is implemented by the Administrator Municipio (Regent), Municipio Distrito Dili is part of the central government within the jurisdiction of the Republic of Indonesia. De Timor-Leste and given the authority to manage their own households including waste management problems, while for implementation at the lowest level, namely those directly dealing with the community as policy targets, it is left to Saniamento Distrto Dili. Abbas and Wee (2014) also revealed that good governance in implementing waste management policies could provide insight to developing countries like Malaysia towards effective waste management. This statement can also apply in other developing countries such as Timor Leste.

\subsubsection{Deployed resources}

a. Financial resources.

According to the records of Saniamento Distrito Dili, the sapah management policy in Distrito Dili was launched in 2008. In its first implementation in 2008, the Timor Leste government disbursed a budget for Distrito Dili Timor Leste amounting to IDR 250 million in 2019, the budget allocation increased to IDR 350 million and human resources deemed sufficient for policy implementation

b. Facilities and infrastructure.

The local government has 8 (eight) units of trucks for transporting garbage in Distrito Dili as reserves and rents 30 private trucks every day, transporting garbage for up to 20 to 25 transportation, working days are every day including Saturdays and Sundays, but due to lack of facilities in the form of trucks transporting garbage, the transportation power of waste from the Temporary disposal site to the Final Disposal Site only reaches 3.60 million $\mathrm{m}^{2}$ and the rest is waste that is not transported.

\subsection{Content of implementation}

4.2.1. Power, interests and strategies of involved actors

Power, the actors involved namely the Minister of Environment of Timor Leste and the Director of Saniamento and it staff are only a description of the highest power, namely the president for the sake of creating a clean and free Timor Leste. This is in accordance with Woodrow Wilson's statement in (Sedarmayanti, 2010: 68) which states that the estuary of bureaucratic reform is the optimization of the infiltration of political interests in the administrative realm which is the land for the bureaucracy to carry out its main task of implementing policies. This means that the political process takes place at the time of policy formulation until the policy is agreed upon, after that let the administration through its bureaucratic instruments, which in this study is Saniamento carrying out its duties properly.

\subsubsection{Characteristics of institutions and rulers}

The characteristics of institutions and authorities in Distrito Dili Timor Leste in implementing waste management policies have had a considerable influence on the implementation of this policy. The characteristics of institutions and authorities in Distrito Dili Timor Leste tend to be democratic and not authoritarian. Institutions and authorities always build good emotional relationships with the community in the areas of markets, housing, schools and offices and shops, but they are not yet open and have not been able to build good communication with the community through the provision of means of submitting complaints. The approach of institutions that build communication with the community in a democratic manner is supported by the findings of Amir and Anto (2018) in their research in Konawe. In the research, it was stated that the Konawe government through its related agencies implemented waste management policies with bottom up communication.

\subsubsection{Compliance and responsiveness of the implementing agent}

In its implementation, the waste management policy implementing agencies in Distrito Dili, Timor Leste are ready and obedient to the success of the leadership's orders, it's just that various weaknesses still accompany the policy's journey such as inadequate facilities, and less guaranteed welfare. This is what affects the implementation of this policy. Similar findings were also expressed 
by Amir and Anto (2014) that efforts to implement waste management policies have been equipped with a workforce who is obedient and committed but their performance has not been maximal because they are not equipped with sufficient infrastructure.

\subsection{Inhibiting factors for implementing solid waste management policies in Distrito Dili, Timor Leste}

Waste management as an aspect of development has an important function in supporting the level of community welfare, because it is related to health, lifestyle, and environmental conditions in settlements as well as comfort in everyday life. Waste management is often seen as a trivial problem, so that it is often marginalized from other things, but in line with the increasing demands for the quality of life of the community, as well as increasing environmental pollution and the limited carrying capacity of the environment itself. Causing waste management to be one of the aspects of development that must be considered. It is still common to find aspects of solid waste management development that are still running independently without any integrated coordination. Poor waste management in an area certainly has their respective inhibiting factors such as policies that are not in accordance with local conditions, lack of government commitment, lack of facilities, working area conditions, public awareness, community participation and low public knowledge (Abbas and Wee, 2014; Amir and Anto, 2018). Therefore, the author describes the factors inhibiting waste management in Distrito Dili Timor Leste, consisting of internal and external factors as follows:

1. Internal factors

\section{a. Human Resources}

Human resources are the most important factor in waste management in Distrito Dili, Timor Leste. All efforts to improve waste management cannot be separated from the aspect of human resources. The technical, managerial and operational capabilities of waste management actors are the main and absolute requirements for better waste management. Limited quality and low quantity of employees are still a problem related to waste management in Distrito Dili, Timor Leste. This causes the waste management in Distrito Dili Timor Leste is still not effective and efficient. Distrito Dili Timor Leste has an area of $170 \mathrm{Km} 2$ and is divided into 6 Districts with a population of 187,000, but the total resources in waste management are only 30 people to manage this large area with a large population. Therefore, the authors can state that human resources in waste management in Distrito Dili Timor Leste are one of the internal inhibiting factors for the ineffectiveness of this policy.

b. Facilities and infrastructure

Limited facilities and infrastructure also became an internal obstacle to the waste management policy in Distrito Dili, Timor Leste. With the increasing volume of waste in Distrito Dili Timor Leste every year but it does not go in line with the provision of facilities and infrastructure that support waste management activities. The Dili Distrito government provides infrastructure in the form of 335 garbage bins (Garbage Bins Units) in every corner of the Dili Distrito but this is still inadequate. Currently, the pile of garbage in the Garbage Disposal Place originating from Distrito Dili has reached 5.85 million $\mathrm{m} 3$, while the location or landfill is only 2 (two) hectares, of which $70 \%$ of the land is currently used or final waste disposal. The driving factor related to facilities and infrastructure is also the availability of garbage trucks. The local government has 8 (eight) units of trucks for transporting waste in Distrito Dili as reserves and rents 30 private trucks every day for the transportation of garbage up to 20 to 25 transportation, working days are every day including Saturdays and Sundays, but due to lack of means transporting garbage, the capacity of transporting waste from the temporary disposal site to the final disposal site (Garbage Disposal Place) only reaches 3.60 million m3 and the rest is waste that is not transported.

c. Legal lawyers are not maximal yet

The economic growth of the people of Timor Leste from year to year is increasing, followed by population growth. This has an increasingly pronounced impact on the environment namely humans tend to damage the environment in order to survive. The quality of the environment is continuously decreasing, causing problems of 
environmental degradation in people's lives. One of the environmental problem is still a problem in Distrito Dili Timor Leste is waste management therefore law enforcement is needed in its implementation.

d. Until now, the sanctions contained in the regulations, especially those concerning waste management, have not provided a deterrent effect for the people of Distrito Dili, Timor Leste who do not carry out waste management in an environmentally sound manner so that it is necessary to study the effectiveness of sanctions in enforcing the law on this waste management policy. In addition, the role of local governments is also very important in issuing policies related to sanctions against irresponsible waste management. If the regions are able to manage their waste properly, the implementation of the principles of Good Environmental Governance has been fulfilled.

2. External Factors

a. Waste Production That Always Increases Each Year

With the stipulation of the City (Distrito) of Dili as the capital of Timor Leste, automatically all activities of the people of Timor Leste will largely be very centralized and concentrated in the city of Dili. This activity, which is centered in Distrito Dili, also contribute to the increase in the volume of waste produced every year because the population of the community is increasing and the community is the main producer of waste itself. It should be noted that the number of population growth in Dili every year continues to increase. In 2017, the total population in Dili City amounted to 277,279 people, increased in 2018 to 293,231 people then increased again in 2019 to 304,889 people as a result that waste that is not properly managed will cause various problems from an aesthetic perspective, this can be seen from piles of garbage in landfills (TPS) and markets. The problem of this waste can also have an impact on public health such as skin diseases, respiratory problems and the potential for environmental disasters arising from the activities and consumption of the community itself.

b. The Awareness of the Distrito Dili Timor Leste Community is Still Low on Proper Waste Management

The people of Dili City think that tackling the waste problem is the sole responsibility of the government. The community plays a more role only as the party who wants to be serve because the community thinks that the Distrito Dili Timor Leste government already has a policy for city cleanliness on every Friday in Dili City such as a cleanliness program for office environments, beaches, public roads and markets so that people do not feel that they are part of the responsibility related to waste problems.

c. Waste Management For Recycling Is Still Low

In urban communities there is a consumptive culture that influences the improvement of the quality and type of waste, including the people of Distrito Dili Timor Leste, which is the capital or capital of Timor Leste. The increasing volume of waste from year to year in Distrito Dili Timor Leste is a strong reason that the waste problem is a major problem that must be resolved in the short, medium and long term. Various efforts by the Distrito Dili Timor Leste government to handle waste have been made, including providing a budget for operational costs and waste management infrastructure. The budget is allocated for the management of landfills (Garbage Disposal Place) and infrastructure for waste management. However, the waste problem is still a serious problem to be handled because the amount of waste generation in Distrito Dili, Timor Leste continues to increase every year. This is because the landfill has limited storage. Currently, almost all of the waste ends up in the Garbage Disposal Place Tibar, so the burden on the Garbage Disposal Place is very heavy and this requires a fairly large area of land and relatively expensive environmental protection facilities.

d. So far, waste management has not been in accordance with environmentally sound waste management methods. Most of the landfill waste management in Timor Leste uses open dumping and landfill methods. The open dumping method is the simplest method, waste is simply dumped in the Garbage Disposal Place without further treatment, while the 
landfill method is that the waste is leveled and compacted with heavy equipment and covered with soil. Both methods are less environmentally friendly because of the potential for contamination of groundwater and air pollution. However, there are also other methods, namely composting, burning, sorting, but for the processing of recycled waste it is not widely used in Distrito Dili Timor Leste so that it contributes to the ineffective waste management policy in Distrito Dili Timor Leste.

\section{Conclusion}

The implementation of local government policies in waste management in Distrito Dili, Timor Leste uses the model of policy implementation theory from Merilee S. Grindle (1980: 11) which states that the success of policy implementation is influenced by the content of policy which results in the following conclusions; (a) the interests of actors involved in implementing waste management policies have not been influenced by waste management policies in Distrito Dili Timor Leste, this is indicated by the ineffective implementation of waste management policies in Distrito Dili Timor Leste, (b) the types of benefits to be generated from the implementation of the policies by the government of Distrito Dili Timor Leste is a healthy and clean environment but in its implementation it has not been effective due to factors of community habits, limited facilities and infrastructure as well as inadequate human resources (c) the degree of change desired in waste management is a comprehensive and comprehensive waste management integrated, it needs to involve the participation of the community and the business world proportionally, effectively and efficiently. It is appropriate to answer the waste problem in Distrito Dili, Timor Leste but has not been effective in the implementation stage (d) the location of policy decision making is based on Bottom Up Decisions (e) implementer of the program is the Central Government of Timor Leste. Administrador Municipio (Regent) and Saniamento Distrto Dili (f) the resources deployed are human, financial and infrastructure resources but not sufficient to support waste management policies in Dsitrito Dili, Tomor Leste.

The conclusions that can be drawn from the policy environment (content of implementation) are (a) the interests affected by the policy, namely the creation of a clean and waste-free Timor Leste, (b) the characteristics of institutions and authorities in Distrito Dili Timor Leste tend to be democratic and not authoritarian but not yet open and unable to build good communication with the community, (c) compliance and responsiveness of the executing actors who are ready and obedient to succeed the leadership's orders, it's just that various weaknesses still accompany this policy journey such as inadequate facilities and less guaranteed welfare.

\section{Limitation and study forward}

This research only discusses the implementation of Dili government policies in overcoming the waste problem. Researchers suggest that further researchers can conduct better research with better data collection methods such as interviews. This would complement the lack of important views on waste management in Dili that were not addressed in this study.

\section{References}

Abbas, Muhamad Azhar and Seow Ta Wee. (2014). The issues of policy implementation on solid waste management in Malaysia. International Journal of Conception on Management and Social Sciences, 2(3), 12-17.

Agustino, Leo. (2016). Dasar-dasar kebijakan publik. Bandung. Alfabeta.

Alex. S. (2002). Sukses mengolah sampah, Yogyakarta. Pustaka Baru Press.

Amir, Muhammad and Rola Pola Anto. (2018). A study policy implementation of the waste management in Konawe Regency Indonesia. Journal of Sustainable Development Canadian Center of Science and Education, 11(1), 90-100.

Dunn, Wiliam N. (2003). Analisis kebijakan publik. Yogyakarta:Gadhah Madha University Press.

Fernando, R.L.S. (2019). Solid waste management of local governments in the Western Province of Sri Lanka: An implementation analysis. www.elsevier.com. Waste management, 84(1), 194203. 
Grindle, Merile S (ed). (1980). Politics and policy implementation in the third New World. New Jersey: Princeton University Press.

Gunawan. G. (2007). Mengolah sampah jadi uang. Transmedia Pustaka, Jakarta.

Hadiwiyoto, Soewedo. (1983). Penanganan dan pemanfaatan sampah. Jakarta: Yayasan Idayu.

Islamy, M Irfan. (2004). Prinsip-prinsip perumusan kebijakan negara. Jakarta: Bumi Aksara

Keban, Yeremias T. (2014). Enam dimensi strategis administrasi publik, konsep, teori dan isu. Edisi Ketiga. Jogjakarta. Gava Media.

Mubarak, W. I., \& Chayatin, N. (2009). Ilmu kesehatan masyarakat: teori dan aplikasi. Jakarta: Penerbit Salemba Medika.

Nasir. Moh, (2008). Metode penelitian. Jakarta. Gahlia Indonesia.

Nugroho. Riant. D. (2006). Kebijakan publik untuk negara-negara berkembang: model-model perumusan, implementasi dan evaluasi. Jakarta. PT. Elex Media Komputindo.

Sedarmayanti. (2010). Reformasi administrasi publik, reformasi birokrasi, dan kepemimpinan masa depan. Bandung: Refika Aditama.

Soenarko SD, H. (2003). Public policy, pengertian pokok untuk memahami dan. menganalisa kebijakan publik. Surabaya: Airlangga University Press

The Liang Gie, (1994). Pertumbuhan daerah pemerintahan daerah di Negara Kesatuan Republik Indonesia. Jakarta. Gunung Agung.

W. Riawan Tjandra. (2009). Peradilan tata usaha negara, mendorong terwujudnya pemerintah yang bersih dan berwibawa. Yogjakarta. Universitas Atma Jaya.

Wahab, Solichin Abdul. (2005). Analisis kebijakan dari formulasi ke implementasi kebijaksanaan negara. Jakarta: Bumi Aksara.

Zulkifli. Arif. (2014). Dasar-dasar ilmu lingkungan. Jakarta. Salemba Teknika. 